\title{
BLASPHEMY IN A SECULAR STATE: SOME REFLECTIONS
}

\author{
Belachew Mekuria Fikre *
}

\begin{abstract}
Anti-blasphemy laws have endured criticism in light of the modern, secular and democratic state system of our time. For example, Ethiopia's criminal law provisions on blasphemous utterances, as well as on outrage to religious peace and feeling, have been maintained unaltered since they were enacted in 1957. However, the shift observed within the international human rights discourse tends to consider anti-blasphemy laws as going against freedom of expression. The recent Human Rights Committee General Comment No. 34 calls for a restrictive application of these laws for the full realisation of many of the rights within the International Covenant on Civil and Political Rights. Secularism and human rights perspectives envisage legal protection to the believer and not the belief. Lessons can be drawn from the legal framework of defamation which considers injuries to the person rather than to institutions or to the impersonal sacred truth. It is argued that secular states can 'promote reverence at the public level for private feelings' through well-recognised laws of defamation and prohibition of hate speech rather than laws of blasphemy. This relocates the role of the state to its proper perspective in the context of its role in promoting interfaith dialogue, harmony and tolerance.
\end{abstract}

\section{Key words}

Blasphemy, Secular, Human Rights, Freedom of Expression, Defamation of Religion

DOI http://dx.doi.org/10.4314/mlr.v7i1.2

\section{Introduction}

The secular as 'an epistemic category', and secularism as a value statement, have been around since the 1640s Peace of Westphalia, otherwise called the 'peace of exhaustion', and they remain one of the contested issues in today's world political discourse. The 1648 Peace Treaties of Westphalia were the

- The writer holds LL.B from Addis Ababa University, MSc from Royal Institute of Technology, Sweden, LL.M and MA from University of Essex and King's College London, United Kingdom, respectively. A PhD candidate at University of Surrey, he is a Lecturer at Addis Ababa University, Center for Human Rights and currently serves as a Legal Research Fellow at the National Institute for Legislative Studies, Nigeria. 
outcome of five years of negotiation that brought to an end the Thirty Years' War. ${ }^{1}$ This Peace, as Derek Croxton describes it, was credited for 'denying altogether the religious basis of secular authority'. ${ }^{2}$ Accordingly, it 'terminated the Pope's claim to universal authority and confirmed the diplomatic independence of secular rulers'. ${ }^{3}$ However, the meaning of the secular is itself in a continuous state of articulation and re-articulation, casting doubts also on its attributes. Scholars continue to question what it means and its desirability for the modern state system. For instance, constitutions of countries astutely declare the separation of state and religion, and the prohibition of the use of the political apparatus for religious agenda. ${ }^{4}$ Does that mean that these legal stipulations alone make that particular country more secular than the ones which do not have these provisions? Or is being secular an attribute of the society, the existence of which requires something more than a legal declaration on the duality of state and religion as such? Calls for a space for religion in a multicultural and democratic context are on the rise, in an open acknowledgement to the changing global dynamics where it is increasingly declared that 'separation of state and religion is no guarantee of free exercise of religion and belief'. ${ }^{5}$ Abdullahi an$\mathrm{Na}$ 'im, a renowned scholar on Islam and human rights, was quoted as saying 'I need a secular state to be a Muslim. ... If I don't have the freedom to disbelieve, I cannot believe' ${ }^{6}$

Where the coercive tools of the state such as the criminal law, family code and institutions by which the state controls societal behaviour are highly dominated by religious ideals of one kind or another, references to that state as secular are open to challenge. ${ }^{7}$ Israel's claim to be a secular state, for example,

\footnotetext{
${ }^{1}$ See Benjamin Straumann (2008), 'The Peace of Westphalia as a Secular Constitution', Constellations, Vol. 15, No 2, pp. 173-188, at 174.

${ }^{2}$ See Derek Croxton, (1999) 'The Peace of Westphalia of 1648 and the Origins of Sovereignty', The International History Review, Vol. 21, No 3, pp. 569-591, at 571.

${ }^{3}$ See Id., at 572 .

${ }^{4}$ According to Article 11 of the Federal Democratic Republic of Ethiopia Constitution, 'state and religion are separate; there shall be no state religion; the state shall not interfere in religious matters and religion shall not interfere in state affairs.' The Federal Republic of Nigeria's Constitution also stipulates under its Article 10 that 'the government of the federation or of a state shall not adopt a state religion.' See Federal Democratic Republic of Ethiopia Constitution, Proclamation No 1/1995, Negarit Gazeta, Year 1 No 1, 21 August 1995, Addis Ababa; and Constitution of the Federal Republic of Nigeria, Decree No 24 of 1999, $5^{\text {th }}$ Day of May 1999.

${ }^{5}$ See Rosalind I.J. Hackett (2006), 'Religious Pluralism in an Undecidedly Secular World', Human Rights, Vol. 33, pp 21-25, at 23.

${ }^{6}$ See ibid.

${ }^{7}$ The Criminal Code of the Federal Democratic Republic of Ethiopia, Proclamation No $414 / 2004,9^{\text {th }}$ May 2005. To examine the Ethiopian example further, its criminal law proscribes blasphemy under its Articles 816 and 492 in varying degrees; See also the
} 
seems merely nominal when one observes the significance that the secular laws place on the 'Jewish Heritage'. Apart from the provision in its Proclamation of Independence defining the State of Israel as a 'Jewish State', a 1980 law of the Knesset provides that:

Where a court is required to decide a legal question for which there is no answer in statutory law, judicial precedent, or by analogy, the question shall be determined in the light of the principles of freedom, justice, equity and peace of the Jewish people. ${ }^{9}$

This stipulation establishes, as S. I. Strong has observed, 'an explicit connection between Jewish law and Israeli secular law', ${ }^{10}$ blurring the line that distinguishes the secular from the religious, the individual from that of the public.

In view of this, the meaning of the secular in today's multicultural setting requires further examination. This article is therefore an attempt to stir up the debate in the context of those states embracing a growing number of religious players with high levels of populist appeal both within and outside the secular space. For this, the doctrine of blasphemy is used, to showcase the dynamics involved in trying to move towards so-called secular statehood.

In the first section of this article, an attempt is made to articulate the concept of secularism in the context of both historical and contemporary settings. Section 2 analyses the law of blasphemy within the secular state system. We shall observe in this section how modernisation has antagonised itself with religiocentrism and continues to push the religious to a separate space of 'the personal' from that of 'the public' or the secular. This shift is to come at the cost of discarding legal protection for the 'sacred' through, amongst other means, the anti-blasphemy laws.

Defamation as a legal framework that considers injuries to the person rather than to institutions, or the impersonal sacred truth, is discussed in Section 3. In

provision on defamation, Article 613. The regional family codes permit multiple marriages in express endorsement of the Islamic laws.

8 The Proclamation of Independence that established the State of Israel lauded the UNGA Resolution 181 of 1947 calling for the establishment of the Jewish State as an acknowledgement of 'the natural right of the Jewish people to be masters of their fate, like all other nations, in their own sovereign state'. See Declaration of the Establishment of the State of Israel 1948, The Provisional Government of Israel Official Gazette, No 1, Tel Aviv, Para 10. By limiting the right to sovereignty to only Jewish people, S.I. Strong argues that 'the Proclamation of Independence could be said to be creating a national identity that advances one trait [being Jewish] at the cost of all others.' See S.I. Strong, (1997) 'Law and religion in Israel and Iran: How the integration of secular and spiritual laws affects human rights and the potential for violence', Michigan Journal of International Law, Vol. 19, pp 109-218, p 146.

${ }^{9}$ See Foundations of Law Act, 5470-1980 cited in S.I. Strong, id, p. 147.

${ }^{10}$ See ibid. 
so doing, the article examines the propriety of repealing blasphemy laws in the light of some recent $\mathrm{UN}$ dispensations that have emerged within the context of enlarging the space for free speech.

\section{The Meaning of the Secular}

On $18^{\text {th }}$ October 2010, BBC Radio channel 4 broadcast an analysis entitled 'Turkey: Staying Secular Insha'Allah.' That statement was made by a woman wearing a headscarf among demonstrators in defence of the Ataturk's Legacy. ${ }^{11}$ She was asked whether she is worried that Turkey will become a Shari'a state, to which she replied 'no, Turkey will remain secular, Insha'Allah'. ${ }^{12}$ The few billionaires in Turkey who are economically vibrant (known as the Anatolian Tigers) are highly Islamist, though the country strives to redefine itself as a secular state for a number of reasons, of which the fundamental one is to integrate itself into the European Union. The deeply entrenched social divisions in the contemporary Turkish polity form a line that separates the religious conservatives and the secularists, the latter viewing the European Union as a guarantor of trust between these two segments. ${ }^{13}$ Those dominant economic actors, though supportive of capitalism, are not that interested in the Western model of liberal democracy and are thus openly critical of the West and anything pro-Western.

The society's day to day life itself is highly informed by this elite's endorsement of religious conservatism. The BBC Radio 4 analysis, also noted that, in Turkey, a person needs to fast, or at least pretend to, as a skill of survival. Failure to observe the main Islamic rituals would result in the loss of a job, or if a trader, the loss of clients. Moreover, as is the case in the UK with regard to the Church of England, the government of Turkey finances the Islamic religion. As Daver once observed, 'almost sixty thousand religious officials receive their salary from the state budget'. ${ }^{14}$ These value differences between the conservatives and those that aspire to redefine the political life of the state towards the secular characterise a number of states in today's world. Mention could immediately be made of such states as Nigeria, Iran, and Egypt.

${ }^{11}$ The Ataturk Legacy is deemed to constitute the basis on which the modern republic of Turkey has been built, which particularly meant the mixture of secularism and nationalism. See in general Cooper, Malcolm (2002), 'The legacy of Ataturk: Turkish political structures and policy making', International Affairs (Royal Institute of International Affairs), Vol. 78, No 1, pp 115-128.

${ }^{12}$ See BBC Radio 4 Analysis, 'Turkey: Staying Secular Insha Allah', 18 Oct 2010.

${ }^{13}$ See Ioannis N. Grigoriadis (2009), 'Islam and Democratisation in Turkey: Secularism and trust in a divided society', Democratisation, Vol. 16, No 6, pp. 1194-1213.

${ }^{14}$ See Bulent Daver, (1969), 'Secularism in Turkey', Review of the Faculty of Political Sciences, University of Ankara, pp 29-40, at 30. 
Simply put, secularism as a modern society's organising principle could mean the separation of state and religion, the former being solely dependent on policies informed by reason, and the latter as a distinct socio-cultural construct that operates on a separate plane. The state as the moderator of the public realm must, of necessity, refrain from sponsoring religions in order to be characterised as secular. Thus, a dualism is supposed to prevail between the public and the private, the political and the religious, reason and a belief in the supernatural, the scientific and the transcendental, the universal and the particular, the democratic and its negation, etc. In this sense, Berkes and Ahmad trace the use of the term secularism to two Latin words; 'Saeculum' and 'Laicism'. ${ }^{15}$ They then note as follows:

While the underlying emphasis in the word [saeculum] is on the idea of worldliness, the term 'laicism' emphasises the distinction of the laity from the clergy. Both terms, however, refer to two aspects of the same thing. They were used in connection with the problems of duality, opposition, or separation of church and state. The church represented the highest authority over the spiritual sphere and the state the highest authority over temporal matters. ${ }^{16}$

Moreover, this dichotomy existed relatively early in the history of the West than in any of the other 'civilisations' as explained by Samuel Huntington. According to Huntington, this distinction has, among other things, contributed immensely to the development of freedom in the West:

Throughout Western history, first the church and then many churches existed apart from the state. God and Caesar, church and state, spiritual authority and temporal authority, have been a prevailing duality in Western culture. Only in Hindu civilisation were religion and politics so distinctly separated. In Islam, God is Caesar; in China and Japan, Caesar is God; in Orthodoxy, God is Caesar's junior partner. The separation and recurring clashes between church and state that typify Western civilisation have existed in no other civilisation. $^{17}$

However, the boundary between these dualities is very much contested. A glance at Turkey, or even Ethiopia or Nigeria, would reveal the challenges that confront a simplistic description of secularism as the separation of state and religion. Even if this dichotomy is claimed to prevail in modern liberal democratic

\footnotetext{
${ }^{15}$ Saeculum originally meant 'age' or 'generation' and later came to refer to 'the temporal world.' And 'laicism' is derived from Greek Laos (the people) and Laikos (the lay). See Niyazi Berkes \& Feroz Ahmad (1998), The Development of Secularism in Turkey, (London: C. Hurst \& Co., Ltd.), p 50.

${ }^{16}$ Ibid.

${ }^{17}$ See Huntington, Samuel (2002), The Clash of Civilizations and Remaking of World Order (United Kingdom: Free Press), at 70.
} 
systems, the influence that each plays over the other is unmistakably clear. The 'in God we trust' declaration on the US dollar note is taken to a higher degree when one observes the Nigerian state's public gatherings. A person from the Western liberal tradition could be taken by utter surprise, if not apprehension, at noticing how every government or non-governmental actor-initiated public gathering can only commence after an opening prayer in the name of 'Allah' and/or 'Jesus.' By far, the most contested aspect in modern secular state of Nigeria is the government's sponsoring of Islamic pilgrimages to Mecca and the Christian pilgrimages to Jerusalem and Rome. ${ }^{18}$

Nonetheless, a categorical classification of Nigeria as a religious polity is thus difficult. In almost all nations of the past and present, religion assumes a pivotal role in what we call the political sphere. This is evident even in American politics: Habermas observed ${ }^{19}$ that 'President Bush has a coalition of primarily religiously motivated voters to thank for his victory' that guaranteed his second term in office against all odds.

The religious threading its way deep into the political is exemplified, for instance, in the family laws of so-called secular states. As Habermas noted, in a number of Muslim countries and in Israel, 'religious family law is either an alternative or a substitute for secular civil law'. ${ }^{20}$ One of the widely debated topics during the revision of the Criminal Code in Ethiopia back in 2004 was whether bigamy should be outlawed without exceptions. The state had to assume a position of an arbitrator while Christian and Muslim values were negotiated. Each side pushing for and against the motion, the ultimate decision would lie in the hands of the professional machinery of politics which undoubtedly thrives by pleasing a substantial majority of its members. In search of the middle, a halfhearted decision was taken, stating that where exceptionally the custom or religion of the spouses permits, bigamy shall not result in criminal prosecution: whilst, in principle, it is a criminal act. ${ }^{21}$

A supportive relation between the state and religious institutions works both ways in the sense that the easy way for a politician to increase their chances of a

${ }^{18}$ The Pilgrims' Board that oversees the Islamic pilgrimages to Mecca led Nigerian Christians to claim to be treated similarly, leading to the birth of 'state-sponsored Christian pilgrimages to Jerusalem and Rome.' See Falola, cited in Afe Adogame, (2010) 'How God became a Nigerian: Religious Impulse and the Unfolding of a Nation', Journal of Contemporary African Studies, Vol. 28, No 4, pp. 479-498, at 487.

${ }^{19}$ Jurgen Habermas (2006), 'Religion in the Public Sphere', European Journal of Philosophy, Vol. 14, No 1, pp. 1-25, at 3.

${ }^{20}$ See Jurgen Habermas (2006), 'Religion in the Public Sphere', European Journal of Philosophy, Vol. 14, No 1, pp. 1-25, at 1.

${ }^{21}$ While Article 650 of the Criminal Code provides for the criminalisation of the act of bigamy, Article 651 provides the exception to it. 
solid win in a constituency is to push for religious values at the top of the policy agenda. The success of the Muslim Brotherhood party in Egypt (until its recent setback due to President Morsi's downfall) primarily rests on its core religious aspirations. The recent events in Egypt have taught the world community historic lessons. We saw the Muslim Brotherhood backing out from the political scene initially to give fuller space for the secular movement to march forward. The demonstrations had brought an unprecedented number of Egyptian women into the streets, with and without headscarves, who loudly chanted slogans, and they would have been unlikely to have been seen if the Egyptian demonstrations were just an Islamic movement. Those events, both in Egypt and elsewhere, have sent a clear message that a society, irrespective of its religious creeds, is willing and able to shape its political apparatus.

The question is whether the events portray the forces of modernity, and of the secular, trying to break religious submissiveness and subservience; or whether the religious values play a unifying role, helping to topple a modern but authoritarian political apparatus. It is in everyone's memory that Tahrir Square served both as a field for worship throughout the 28 days of perseverance and a peaceful battleground in defence of democracy. Which was instrumental for which, religion or modernity as a value statement of the secular, is not yet clear.

It is therefore crucial to acknowledge the fact that the 'religious and the secular do not simply compete with one another but', as Banu argues, they 'also intersect in complex and sometimes contradictory ways'. ${ }^{22}$ Once we note the impossibility of containing the religious within a compartmentalised 'sacred space', it is much easier for us to agree with one of the central conclusions of Talal Asad which reads:

secular state is not one characterised by religious indifference, or rational ethics - or political toleration. It is a complex arrangement of legal reasoning, moral practice, and political authority. This arrangement is not the simple outcome of the struggle of secular reason against the despotism of religious authority. ${ }^{23}$

\section{Blasphemy in a Secular State}

We have seen the difficulties involved in drawing up a clear boundary between what is religious and what is secular. In other words, it is submitted that even in modernity at its best, and where secularism is expressly upheld as a constitutional virtue, it is hardly possible for the two spheres to neatly operate

${ }^{22}$ See Banu Gokariksel (2009), 'Beyond the Officially Secular: Religion, secularism and the body in the production of subjectivity', Social and Cultural Geography, Vol. 10, No 6, pp 657-674, at 658.

${ }^{23}$ See Talal Asad (2003), Formations of the Secular: Christianity, Islam, Modernity (Stanford University Press, California), p. 255. 
independently of one another. One area where the secular state has, throughout history, failed to keep itself away from the religious lives of individuals is the law of blasphemy. This is defined, rather simplistically, by St. Thomas Aquinas as referring to an act meant 'to cast insult or abuse at the dignity of our creator'. ${ }^{24}$ However, this cannot be the correct interpretation of the act of blasphemy as noted by Asad who wrote, 'unlike the Christian concept of Godhead, Muslims insist that God is not a person - and therefore honour or dishonour cannot accrue to him'. ${ }^{25}$ That being theological discourse, this contribution would not touch, it suffices to mention that, whether in Islam or Christianity, blasphemy is meant to provide protection to 'sacred truths' that followers of a particular religion dearly hold on to.

The emergence of the law in this area in the English legal system, for instance, is traced back to the case of $R v$ Taylor in 1677, by which the King's Bench convicted a man who had described Christ in a degrading manner and religion as a fraud. Lord Chief Justice Hale commented that:

...to say religion is a cheat, is to dissolve all those obligations whereby the civil societies are preserved, and that Christianity is parcel of the laws of England; and therefore to reproach the Christian religion is to speak in subversion of the law. ${ }^{26}$

Thus first, this law of blasphemy was exclusively meant to apply to the Church of England, and second, blasphemous utterances were regarded offensive not only to God but also the State, as they were deemed subversive of the law. After a long period of time, in 1995, blasphemy was re-articulated to regulate the form rather than the substance of a statement in and of itself. In other words, denying the existence of God per se, let alone to label religion as a fraud, would not be considered as subversive; rather, to avoid transgressing the blasphemy laws, the manner in which the views are expressed must not be offensive. In the case of $R$ $v$ Lemon, before the House of Lords in explaining the exact meaning of blasphemy, Lord Scarman stated the following:

${ }^{24}$ See Reid Mortensen (1994), 'Blasphemy in a Secular State: A pardonable sin?' UNSW Law Journal, Vol. 17, No 2, pp 409-431, at 410.

${ }^{25}$ Talal Asad (2008), 'Reflections on Blasphemy and Secular Criticism', in Hent de Vries (Ed.), Religion: Beyond a Concept, (Fordham University Press), at 29.

${ }^{26} \mathrm{R} v$ Taylor (1677), quoted in Mortensen, supra note 24, p 411; It is striking to note that the punishment was not that articulated and included a number of measures against the 'offender.' Mr. Taylor, the defendant, 'uttered orally many highly offensive words against religion, words so wildly violent as to suggest doubts of his sanity [for which] he was fined and ordered to be pilloried thrice and to find sureties for his good behaviour throughout his life'. See Kenny, Courtney (1922), 'The evolution of the law of blasphemy', The Cambridge Law Journal, Vol. 1, No 2, pp 127-142, at 129. 
It is not blasphemous to speak or publish opinions hostile to the Christian religion or to deny the existence of God, if the publication is couched in decent and temperate language. The test to be applied is as to the manner in which the doctrines are advocated and not as to the substance of the doctrines themselves. ${ }^{27}$

The last conviction for the crime of blasphemy in the UK was in 1922, when William Gott was found guilty of this crime and 'served nine months of hard labour for distributing pamphlets describing how Jesus Christ entered Jerusalem because Gott used words ${ }^{28}$ which were considered blasphemous. This conviction has over time been challenged as illiberal, in the sense that it restricts freedom of expression, which stands as a pillar for modern secular and democratic society. In submitting the proposal to the House of Commons for the abolition of the law of blasphemy, the Liberal Democrat MP Dr. Evan Harris had described the reasons for the abolition to be twofold:

...the offence of blasphemy is illiberal because its scope is uncertain ...The offence is discriminatory in that it applies only to the Christian religion-and within that, only to the tenets of the Church of England. ${ }^{29}$

Intrinsically therefore, the law of blasphemy was meant to resolve conflicts, as it were, that emerge between plaintiffs representing Christian values, and defendants who by their statements or actions have injured the former. Nevertheless, where the state and its institutions are expected to operate tangentially from religion, this form of intrusion into the 'private' sphere is highly problematic. This being a brief account of the Western and so-called secular view on blasphemy, ${ }^{30}$ it stands on a direct collision course with the

${ }^{27} R$ v Lemon, quoted in Clive Unsworth (1995), 'Blasphemy, Cultural Divergence and Legal Relativism', The Modern Law Review, Vol. 58, No 5, pp 658-677, at 662.

${ }^{28}$ See Rex v Gott, 1922, p 89, cited in Robert C. Blitt, (2011) 'The bottom up journey of 'defamation of religion' from Muslim States to the United Nations: A case study of the migration of anti-constitutional ideas', in Austin Sarat (ed.), Human rights: New possibilities/new problems, Special Issue Studies in Law, Politics and Society, Vol. 56, pp. 121-211.

${ }^{29}$ See Lucinda Maer (2008), The Abolition of the Blasphemy Offences, House of Commons, Parliament and Constitution Centre, SN/PC/04597, (House of Commons Library), at 4. The House of Lords had passed the motion for the amendment Bill by 148 to 87 , and it was then confirmed by the House of Commons with 378 to 57 . The Bill received Royal Assent on 8 May 2008.

${ }^{30}$ In this regard, one must not make the mistake of thinking all Western traditions do not outlaw acts of blasphemy. Mention could be made of Canada, Denmark, Germany, Greece, Ireland, Italy, Malta, the Netherlands, and Poland. See Brian J. Grim, (12 Nov 2012), Laws penalising blasphemy, apostasy and defamation of religion are widespread, Pew Forum on Religion and Public Life, 
Islamic subject. This is because the latter holds that 'any statement defaming a religion was equal to a racist statement... and therefore, had nothing to do with the enjoyment of the right to freedom of expression'. ${ }^{31}$

This, however, emerges from the long-standing error of conflating injuries on an individual with that of an establishment, whether religious or other. Human rights apply to individuals, and as such 'international human rights law protects such individuals from discrimination [racist, religious, political, etc] but does not protect the religion itself' ${ }^{32}$ In this regard Rebecca Ross concludes, after arguing against Canada's criminal law provision on blasphemy [that had not been applied since 1936], that such laws violate freedom of expression, 'particularly because unlike ethnicity, it is expression itself that creates religious doctrine and tradition'. ${ }^{33}$ Moreover, the conflation of religion with that of race is similar to considering a mutable trait of human life as an immutable one. L. Bennett Graham criticises this trend as follows:

While there is often a relationship between these characteristics, the conflation of these concepts has confused the legal protections for each of them. Race, an immutable characteristic, is treated by the law differently than is religion. Article 18 of the Universal Declaration of Human Rights (UDHR) guarantees the right to change one's religion... If race and religion continue to be conflated, this right will continue to be undermined as religion becomes defined as an immutable trait. ${ }^{34}$

\footnotetext{
$<$ http://www.pewforum.org/Government/Laws-Penalizing-Blasphemy,-Apostasy-andDefamation-of-Religion-are-Widespread.aspx > last visited 14 Feb 2013; for a critique of Canadian blasphemy law, see Rebecca Ross, (2012), 'Blasphemy and the Modern, 'Secular' State', Appeal: Review of Current Law and Law Reform, Vol. 17, pp. 3-20.

31 This statement was made by an Azerbaijani representative to the UN when the resolution on defamation of religion was discussed. Quoted in Rebecca J. Dobras, (2009), 'Is the United Nations endorsing human rights violations?: An analysis of the United Nations combating defamation of religions resolutions and Pakistan's blasphemy laws', Georgia Journal of International and Comparative Law, Vol. 37, pp. 339-380, at 365 .

${ }^{32}$ See Rebecca J. Dobras, id, p. 367.

${ }_{33}^{3}$ See Robecca Ross, supra note 30, p. 18.

${ }^{34}$ See L. Bennett Graham, (2009), 'Defamation of Religions: The End of Pluralism?' Emory International Law Review, Vol. 23, pp 69-84, at 78; it is important to note that the right to change one's religion is one of the rights that do not feature in the International Covenant on Civil and Political Rights just settled with 'the freedom to have or to adopt a religion or belief of his choice', substituting the UDHR's stipulation of 'the freedom to change his religion or belief'. See art 18, UNGA, Universal Declaration of Human Rights, 10 December 1948, 217 A (III); also see art 18(1), UNGA, International Covenant on Civil and Political Rights, 16 December 1966, GA Res 2200 A (XXI), United Nations Treaty Series, Vol. 999, p. 171.
} 
It is also submitted that such laws principally aspire to prevent conflicts and public disorder in multicultural and pluralistic settings and that very fact alone justifies their existence. But is that really so? Blasphemy is essentially, though not exclusively, a crime committed (and not omitted) through statements that are deemed offensive and thus are meant to restrict one's freedom of expression. Simply put, it is a 'linguistic offence ... and specifically the contested use of language in respect of the sacred'. ${ }^{35}$ Any purpose that a law of this or any other type desires to achieve must, of necessity, be proportional to the 'costs' involved, or sacrifices to be made - in this case, the restraint on one's fundamental human right.

The possibility of restrictions on freedom of expression is less contested, as this is one of the freedoms that are subject to limits by the law in any democratic society. Article 10 of the European Convention of Human Rights stipulates that 'the exercise of [freedom of expression] ... may be subject to such formalities, conditions, restrictions or penalties as are prescribed by law and are necessary in a democratic society'. ${ }^{36}$ Similarly, Article 19 of the International Covenant on Civil and Political Rights, after guaranteeing freedom of expression for all, provides for limitations to be imposed by law which are necessary for the respect of the rights or reputation of others, for the protection of national security, public order, public health or morals. ${ }^{37}$

However, whether such restriction is worth imposing through the law of blasphemy is not that simple to assess. It was even argued that the continued existence of the law of blasphemy violates the right to freedom of expression, and the right not to be discriminated against on grounds of religion. ${ }^{38}$ To say that blasphemy law plays a role in maintaining public order is also not convincing unless this proceeds from a flawed presupposition that giving offence to religious values would invariably result in public disorder. Many believe the contrary and that in countries like Pakistan, the blasphemy law that prescribes an extreme punishment, the death penalty, is a cause of rather than a panacea for public disorder. ${ }^{39}$

A more serious challenge confronting blasphemy law in today's world is cultural and religious pluralism that has become increasingly pronounced across societies and civilisations. Hitherto, under-privileged religious and cultural groups have started to demand a central place in the lives of individuals, using the law of blasphemy to request the prosecution of those whom they consider to

${ }^{35}$ See Clive Unsworth, supra note 27, p. 674.

${ }^{36}$ See European Convention of Human Rights (1950), Article 10(2)

${ }^{37}$ Article 19 (2) \& (3) of the United Nations International Covenant on Civil and Political Rights (1966).

${ }^{38}$ Supra note $15, \mathrm{p} 6$.

${ }^{39}$ See Rebecca J. Dobras, supra note 31, p. 355 ff. 
have offended their values. Salman Rushdie's The Satanic Verses, and the Danish cartoons are but two of the most recent examples that Western societies have confronted in the last two decades after the Cold War. The demands for political action via the crime of blasphemy were refused, leading to a bitter response and a number of self-help measures taken by organised Muslim communities.

The overall controversy on blasphemy is symptomatic of the shift, as noted by Unsworth, of the 'focus of political authority from the structural and institutional to the discursive, to the ways in which phenomena are represented and struggles over meaning'. ${ }^{40}$ Resolving such controversy, either through a universalised blasphemy law or through multiple stipulations based on the distinct religious doctrines is both economically and intellectually taxing, and not worth trying. One option is to say that the state must retain its temporal authority and regulate social behaviour through its coercive tools of executive fiat, prevent crimes, distribute losses through economic laws such as tort, and deter potential perpetrators by imposing calculated pain on those who have offended the penal system. However, this authority has to operate within the bounds of neutrality by not engaging in wholesale or piecemeal sponsoring of religious values. As noted above, this level of neutrality is, nonetheless, very unlikely to be achieved.

Blasphemy also presupposes a collective form of injury, as it relates to a violation by expressions (written or verbal) directed against sacred truths that permeate a particular religion. Proving this form of collective injury is arduous, both from the perspective of the defendants' guilty state of mind (mens rea) as well as from the contents of the act itself- actus reus. The Law Commission of England, based on the referral made to it by the House of Lords, produced a Working Paper in which it had expressed its concern on the indefiniteness of the mens rea required by the blasphemy $\operatorname{law}^{41}$ as well as about the uncertainties of its actus reus. ${ }^{42}$ It noted the difficulty involved in concretely defining, for legislative and adjudicative purposes, the terms 'church' and 'religion.' The following remarks in New Law Journal are worth noting:

'... criminal sanctions in support of the preservation of a shared, collective social respect for religion cannot rationally be sustained. On the other hand,

${ }^{40}$ See Clive Unsworth, supra note 27, p. 675.

${ }^{41}$ The Law Commission Working Paper No 79, cited in Micklewright, F.H. Amphlett (1981), 'Blasphemy and the Law Commission', Law and Justice-Christian Law Review, Vol. 7071, pp. 109-115, at 110.

${ }^{42}$ See Robilliard, John (1981), 'Offences against Religion and Public Worship', The Modern Law Review, Vol. 44, No. 5, pp 556-563, at 556. 
the argument for promoting reverence at the public level for the private feelings of individual behaviours remains the highest validity. ${ }^{43}$

This quote from the New Law Journal brings us to an important 'compromise' that modern, secular states could legitimately pursue as an alternative to the law of blasphemy. This is to 'promote reverence at the public level for private feelings' through the well-recognised laws of defamation. The notion of the law of defamation 'professes to protect personal character ... without sacrificing freedom of thought and the benefit of public discussion'. ${ }^{44}$ So this shift from the collective to the individual, and from the illiberal to the liberal views on faulty expressions, would relocate the role of the state to its proper perspective.

Similarly, one of the contested aspects of the UN resolutions on 'defamation of religion, 45 has been the absence of a clear definition for both the word 'defamation' as well as the required state of mind on the part of the perpetrator. While the proponents of the resolutions championed the idea of providing a special place for Islam, the opponents have clearly argued against it as being discriminatory towards other world religions. With regard to mens rea, the dominant view envisages that the act should be intended to incite public disorder. This can properly be covered by other laws like the prohibition on hate speech and must not be the concern to the law of blasphemy. This is because unlike hate speech, blasphemy laws do not require hateful intent and

${ }^{43}$ New Law Journal, quoted in Micklewright, supra note 23.

${ }^{44}$ See, Van Vechten Veeder (1903), 'The History and Theory of the Law of Defamation', Columbia Law Review, Vol. 3, No 8, pp 546-573, at 546.

${ }^{45}$ It is crucial to note that 'defamation of religion' as understood by the proponents of those UN resolutions that began in 1999, and which was followed by the adoption of at least one resolution every year for over 10 years, is more or less similar to the law of blasphemy. In one of its policy papers, the International Humanist and Ethical Union (IHEU), an organisation that consistently opposed the resolutions, identifies the striking similarities between defamation of religion and blasphemy in the following words:

The concept of "defamation of religion" shares many characteristics with the concept of 'blasphemy' found in anti-blasphemy laws: both concepts favour the ideas and institutions of religion over the conscience and expressions of the individual; both favour politically powerful forms of religion over dissenting and minority forms of religions; and both favour religious beliefs over non-religious beliefs. As a result, both prohibit critical evaluation and debate about religions and religious institutions in a position of power. And both restrict free inquiry and freedom to compare and choose between beliefs.

See Matt Cherry and Roy Brown, (21 October 2009), 'Speaking freely about religion: religious freedom, defamation and blasphemy', IHEU Policy Paper, $<$ http://www.iheu.org/files/Speaking\%20Freely\%20about\%20Religion.pdf > last visited 19 February 2013. 
accordingly, 'punishing a speech that involves no hateful intent violates freedom of expression'. ${ }^{46}$

The concept of 'Margin of Appreciation' needs to be noted in relation with the balance between freedom of expression and blasphemy laws. This concept gives recognition for variation in the application of freedom of expression in different contexts. This can be illustrated by the decisions of the European Court of Human Rights in Wingrove $v$ United Kingdom and Otto-Preminger v Austria.

The application of Nigel Windgrove for a classification certificate to a film titled 'Visions of Ecstasy' was rejected by the British Board of Film Classification "pursuant to the Video Recordings Act 1984, not because of its sexual imagery but on the ground that the video infringed the criminal law of blasphemy". "His appeal to the European Court of Human Rights was not successful because the European Court by a majority of seven votes to two, found that national authorities are "entitled to consider that the impugned measure was justified as being necessary in a democratic society within the meaning of paragraph 2 of Article 10" and "there is no violation of Article 10 of the Convention". ${ }^{4}$

The Court recalled that "freedom of expression constitutes one of the essential foundations of a democratic society" under Article 10(2) of the Convention, but meanwhile stated that this right carries with it duties and responsibilities including "a duty to avoid as far as possible an expression that is, in regard to objects of veneration, gratuitously offensive to others and profanatory". 49 The European court held that:

In examining whether restrictions to the rights and freedoms guaranteed by the Convention can be considered 'necessary in a democratic society' ... the Contracting States enjoy a certain but not unlimited margin of appreciation. It is, in any event, for the European Court to give a final ruling on the restriction's compatibility with the Convention and it will do so by assessing in the circumstances of a particular case, inter alia, whether the interference corresponded to a 'pressing social need' and whether it was 'proportionate to the legitimate aim pursued' 50

This decision was preceded by Otto-Preminger Institute v. Austria ${ }^{51}$ in which the applicant's attempt to show a film offended the religious feelings of the

${ }^{46}$ See Rebecca J. Dobras, supra note 31, p. 356.

${ }^{47}$ Stephanie Palmer (1997), "Blasphemy and the Margin of Appreciation" The Cambridge Law Journal, Vol. 56, No. 3 (November 1997), p. 470.

${ }^{48}$ Wingrove $v$ The United Kingdom, 17419/90 [Chamber Judgment [1996] ECHR 60 (25 November 1996], para 62.

${ }^{49} \mathrm{Id}$, para 52.

${ }^{50} \mathrm{Id}$, para 53.

51 Otto-Preminger-Institut v. Austria, (13470/87) [1994] ECHR 26 (20 September 1994) 
many Catholics in Tyrol (which is inhabited by a large majority of Catholics). The film was banned by Austrian authorities. Upon appeal, the European Court of Human Rights upheld the ban by extending "the margin of appreciation to Austrian Catholics in recognition of their greater religious sensitivity". ${ }^{52} \mathrm{Kahn}$ duly raises the issue whether it is "possible to extend the same "margin of appreciation' to Muslims (especially those in Europe) who in response to antiMuslim speech and acts have called for laws punishing the defamation of religions?"53

\section{3. 'Blasphemy' under Ethiopian law}

Articles 27 and 90 of the FDRE Constitution provide for freedom of religion and at the same time state the grounds for limiting this freedom. While sub-Articles 1 to 4 of Article 27 deal with freedom of religion, sub-Article 5 indicates the possible limitations "as are prescribed by law ... to protect public safety, peace, health, education, public morality or the fundamental rights and freedoms of others, and to ensure the independence of the state from religion". The words 'independence of the state from religion' articulate secularism. The fact that education shall be "free from any religious influence, political partisanship or cultural prejudices" as enshrined in Article 90(2) of the FDRE Constitution further shows the level of secularism envisaged under Ethiopia's Constitution. The scope of this article, however, does not allow detailed discussion on these constitutional provisions, and particular attention is given to two specific provisions that deal with blasphemy under Ethiopia's 2004 Criminal Code.

The Ethiopian law on blasphemy has two parts: while the first could be said to proscribe an act of defaming a religion, the second, classified as a petty offence, relates to the criminalisation of blasphemous utterances. ${ }^{54}$ This is also an area of the criminal law that has seen no change during the revision of the 1957 Penal Code of Ethiopia. ${ }^{55}$ The first of these two crimes, titled 'outrage on religious peace and feeling', under Article 492 of the 2004 Criminal Code, reads as follows:

${ }^{52}$ Robert A. Kahn (2010), Tragedy a Margin of Appreciation for Muslims? Viewing the Defamations of Religions Debate through Otto-Preminger Institute v. Austria (University of Thomas School of Law, Legal Studies Research Paper, No. 10-27), p. 3.

${ }^{53}$ Ibid.

${ }^{54}$ See art 492 of the Criminal Code for defamation of religion and art 816 for blasphemous or scandalous utterances or attitudes.

${ }^{55}$ These two crimes were provided for in exactly the same way under the repealed Penal Code, by Articles 486 and 771 respectively. 
Whoever publicly ${ }^{56}$

a) prevents the solemnisation of, or disturbs or scoffs at, an authorised religious ceremony or office, or

b) profanes a place, image or object used for religious ceremonies, is punishable with a fine not exceeding one thousand Birr, or with simple imprisonment not exceeding two years.

According to this provision, an act would be regarded as an outrage on religious peace and feeling not only because of the perpetrator's intent of doing those injurious deeds, but also because of its being 'public.' Therefore, this publicity requirement is the essence that renders the act an outrage to 'religious peace and feeling.' The crime of defamation is also underpinned by a similar requirement, as it must be addressed to a 'third party' with the intent to injure the honour or reputation of the victim. ${ }^{57}$ There is, however, a clear difference in the nature of 'publicity', in the sense that, for defamation, communicating the defamatory word or act to a single third party is enough to meet this requirement. When it comes to outrage on religious peace and feeling, the acts of preventing or disturbing religious ceremonies or profaning religious place, images or objects may hardly fulfil the act's requirement under this provision if they are done before only a single third party.

The other provision of the 2004 Criminal Code which directly deals with blasphemy is Article 816. It applies where a person:

in a public place or in a place open to the public or that can be viewed by the public, by gestures or words scoffs at religion or expresses himself in a manner which is blasphemous, scandalous or grossly offensive to the feelings or convictions of others or towards the Divine Being or the religious symbols, rites or religious personages. ${ }^{58}$

This provision falls under the Code of Petty Offences and imposes a punishment of fine or arrest not exceeding one month. The lighter punishment to be imposed and the requirement complaint by an aggrieve party in all petty crimes usually makes those sections of the Ethiopian criminal law relatively lenient compared to the category of 'serious' crimes. ${ }^{59}$

\footnotetext{
${ }^{56}$ The Amharic version of this statement has a clear indication of the mensrea as it says

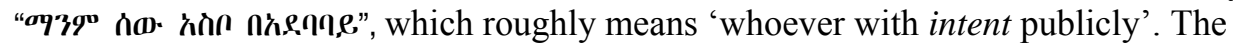
usual invocation of the Negarit Gazette Establishment Proclamation Article 4(2) would, therefore, support our preference for this Amharic version and the required mental element is 'intention.' See Federal Negarit Gazette Establishment Proclamation 3/1995, Federal Negarit Gazette, Year 1, No 3, 22 August 1995.

${ }^{57}$ See article 613 of the Criminal Code.

${ }^{58}$ See article 816 of the Criminal Code.

${ }^{59}$ See generally Franklin F. Russell (1961), 'The New Ethiopian Penal Code', The American Journal of Comparative Law, Vol. 10, No 3, pp. 265-277.
} 
Distinction in the levels of criminalisation of these acts (that essentially describe blasphemy in one way or the other) lacks clear articulation. What is being protected by Article 492 - whether it is the religion or the religious person - is not apparent. The reference in the title to an 'outrage to religious feeling' gives the impression that it underscores the human aspect of the injury caused by the act, as one may hardly attribute a 'feeling' to a religion. One would observe that Article 492(a), under which the perpetrator disturbs the religious ceremony, deals with an outrage to religious peace. And Article 492(b) is more of an outrage to a religious feeling that a believer has towards a religious place, image or object.

The first aspect of that provision implies that the religion and not the believer is the one within its purview of protection. This personification of religion, for purposes of criminal liability, renders the provision problematic when it comes to real life application. On the basis of the secularism and human rights perspectives concerning the subject, the law should aspire to protect the believer and not religion per se.

Since the year 1999, the UN has been adopting resolutions aimed at the protection of religion against defamation, about which Rebecca Dobras has provided a comprehensive review showing the views of opponents and proponents. ${ }^{60}$ The passage of the resolutions was highly influenced by the Organisation of the Islamic Conference (OIC), which mobilised support from member states. ${ }^{61}$ As is evident from the recently adopted General Comment No. 34 of the Human Rights Committee, the position of opponents has obtained greater influence. As Dobras notes:

The opposing states expressed concern that the Defamation Resolutions address religion, an issue that had never before been the subject of international protection. Opponents argue that the defamation of religion is not always a recognised human right. International human rights law protects individuals from discrimination but does not protect the religion itself. So in order for there to be a human rights violation, the action must incite discrimination or interfere with an individual's religious freedom... Similarly, the International Humanist and Ethical Union (IHEU) main representative stated, 'lack of respect for a belief should not be confused with hatred of the believer,' and 'it is the believer that merits protection, not the belief' ${ }^{62}$

${ }^{60}$ See Rebecca J. Dobras, supra note 31; for the complete list of those resolutions, see the Rebecca J Dobras footnote 5, p. 341.

${ }^{61}$ She noted that "no Western country has ever voted in favour of any of the defamation resolutions, arguing they focus selectively on Islam; protect the religion itself instead of protecting individuals from religious discrimination, and unlawfully restrict freedom of expression'. Rebecca J. Dobras, supra note 31, p. 342.

${ }^{62}$ See Rebecca J Dobras, supra note 31, pp. 367-368 
The terminology 'defamation of religion' within the context of the UN resolutions encountered a serious setback when the recently adopted Human Rights Council Resolution re-articulated the concept in a more neutral frame. The Resolution, 16/18, titled, 'combating intolerance, negative stereotyping and stigmatisation of, and discrimination, incitement to violence and violence against, persons based on religion or belief' has omitted the use of defamation of religion. ${ }^{63}$ As can be discerned from this title, it is the "persons of religion or belief' who merit protection and the resolution rather underscores the need for interfaith and intercultural dialogue. To this end, the resolution recognises:

... that the open public debate of ideas, as well as interfaith and intercultural dialogue, at the local, national and international levels can be among the best protections against religious intolerance and can play a positive role in strengthening democracy and combating religious hatred, and ... that a continuing dialogue on these issues can help overcome existing misperceptions. ${ }^{64}$

Subsequently, the Human Rights Committee adopted its latest General Comment No. 34 on 'Freedoms of Opinion and Expression' that directly declares laws of blasphemy objectionable in light of the Covenant provisions:

Prohibitions of displays of lack of respect for a religion or other belief system, including blasphemy laws, are incompatible with the Covenant, except in the specific circumstances envisaged in Article 20, paragraph 2, of the Covenant. Such prohibitions must also comply with the strict requirements of Article 19, paragraph 3, as well as such Articles as 2, 5, 17, 18 and 26. Thus, for instance, it would be impermissible for any such laws to discriminate in favour of or against one or certain religions or belief systems, or their adherents over another, or religious believers over non-believers. Nor would it be permissible for such prohibitions to be used to prevent or punish criticism of religious leaders or commentary on religious doctrine and tenets of faith. ${ }^{65}$

The current human rights discourse appears, therefore, to be shifting towards a restrictive use of blasphemy laws only within the context of 'hate speech', which can be applied as a legitimate ground to restrict free speech because of the content of the act or utterances that may be deemed as an advocacy to incite discrimination, hostility or violence of a national, racial, or religious nature. ${ }^{66}$

${ }^{63}$ See United Nations Human Rights Council, 'Combating intolerance, negative stereotyping and stigmatisation of, and discrimination, incitement to violence and violence against, persons based on religion or belief', 12 April, A/HRC/RES/16/18.

${ }^{64}$ See the Resolution 16/18, id., para 4.

${ }^{65}$ See Human Rights Committee, 'General Comment No. 34: Article 19: Freedoms of opinion and expression' 21 July 2011, CCPR/C/GC/34, para 48.

${ }^{66}$ See Art 20(2) of the International Covenant on Civil and Political Rights. 
With regard to Article 492 of the Ethiopian Criminal Code, the provision does not seem to relate to hate speech nor to objectionable acts of blasphemy in its totality. This is because the provision does not specifically consider utterances or speech as the act constituting the violation under its ambit. Although some of its aspects could be regarded as blasphemy, the classical understanding of it, as 'irreverence toward God, religion, a religious icon, or something else considered sacred', ${ }^{67}$ is more related to Article 816 than an 'outrage to religious peace and feeling' envisaged under Article 492. Objective standards are missing to judiciously determine what may constitute 'an authorised religious ceremony', 'profaning ("7chn) of religious places, images or objects', and as to what may be regarded as outrage to religious feeling.

Article 492 thus opens the door for open-ended and incomprehensible issues that are difficult to answer. Criticisms are mounting globally from the perspective of secular and democratic states thereby necessitating objective standards and clarity with regard to Article 492. Moreover, a revisit to the petty offence provision on blasphemy (under Article 816) is necessary because the provision takes non-verifiable sacred truths (and not the believer) as deserving protection. The very idea of including the blasphemy provision within the petty offences section of the 1957 Penal Code (and then under a similar section of the 2004 Criminal Code) indicates the societal readiness for tolerance towards religious criticisms within the multicultural and multi-religious context. Whether we still have to maintain this provision and refrain from enhancing the level of tolerance in freedom of expression is an issue the legislature needs to attend to.

\section{Conclusion}

The focus on the human dignity of individuals as subjects of violation, rather than religious truths affecting a collectivity, will enable us to establish objective criteria for proof of violations. The 'reasonable person' standard, applied routinely in secular democratic societies as a measure of good behaviour, cannot function as such in blasphemy trials or so-called crimes of 'defamation of religion.' The modern laws of secular societies also provide protection to group sensibilities based on race, religion, ethnicity, colour, etc., and penalise 'hostile expressions directed towards a person on the basis of [those] characteristics'. However, blasphemy - in its contemporary understanding, basically consists of 'vilification of [religious] beliefs (rather than believers)'. ${ }^{68}$ It was stated that

${ }^{67}$ See Maxim Grinberg, (2006), 'Defamation of religions v. Freedom of expression: Finding the balance in a democratic society", Sri Lanka Journal of International Law, Vol. 18, pp. 197-222, at 211.

${ }^{68}$ See Harris, Bed (1998), 'Should Blasphemy be a Crime? The 'Piss Christ' Case and Freedom of Expression', Melbourne University Law Review, Vol, 22, pp 217-229, at 224. 
John Locke 'believed the Christian religion to be true but did not know it to be true and resolved that no political institution could make any stronger claim' ${ }^{69}$ This clearly makes a distinction between empirical knowledge and mere belief, and strictly speaking the state is not in a position to 'define religious truths and errors' ${ }^{70}$

The law of blasphemy militates against freedom of expression for it criminalises a speech which is considered injurious to a particular religion, irrespective of the mental state of the perpetrator. In a democratic setting where there exists a 'wall of separation' between state and religion, 'that wall must be kept high and impregnable. ${ }^{, 71}$ The Ethiopian criminal law provisions treat the subject in two different headings within the special part as well as the petty offences section: while the first exhibits a case where an act of disturbance on and profaning of religious ceremonies or objects is criminalised, the other explicitly prohibits blasphemous utterances. The subjective character of religious peace as well as feeling stated under Article 492 of the Criminal Code denies it meaning and practical application. The petty offences section on blasphemy is also anachronistic in a democracy and accordingly requires revising. This becomes more pressing if the country has to live up to its human rights commitment under the International Covenant on Civil and Political rights.

${ }^{69}$ Mortensen, supra note 24, p 426.

${ }^{70}$ Ibid.

${ }^{71}$ See Thomas Jefferson's Letter to the Danbury Baptists, 1 January 1802, First Principles Series, the Heritage Foundation $<\mathrm{http}$ ://www.heritage.org/initiatives/firstprinciples/primary-sources/jefferson-s-letter-to-the-danbury-baptists $>$ last visited 21 February 2013. 